\title{
Leptin Suppresses Glutamate-Induced Apoptosis Through Regulation of ERK1/2 Signaling Pathways in Rat Primary Astrocytes
}

\author{
Hyunju Park ${ }^{\mathrm{a}}$ So-Hee Ahn ${ }^{\mathrm{a}}$ Yieun Jung ${ }^{\mathrm{a}}$ Joo Chun Yoon ${ }^{\mathrm{b}} \quad$ Youn-Hee Choi \\ aDepartments of Physiology, Tissue Injury Defense Research Center, Ewha Womans University School of \\ Medicine, Seoul, 'Departments of Microbiology, Ewha Womans University School of Medicine, Seoul, \\ Korea
}

\author{
Key Words \\ Leptin • Glutamate $\cdot$ ERK1/2 • Astrocytes
}

\begin{abstract}
Background/Aims: Leptin is a hormone expressed by adipose tissue that regulates body energy homeostasis and weight loss by activating leptin receptors in the hypothalamus. Leptin receptors are also expressed in astrocytes. An anti-apoptosis effect of leptin in brain has recently been reported. However, the anti-apoptosis mechanism of leptin in the brain is unknown. Methods: To investigate whether leptin exerts protective effects against glutamateinduced apoptosis in astrocytes, we performed cell viability assays and apoptosis assays using rat primary astrocytes. Intracellular signaling pathways involved in anti-apoptosis effects of leptin were analyzed by immunoblotting together with a leptin mutant (S120A/T121A) with antagonist function and pharmacological inhibitors. Results: We found that glutamateinduced apoptosis in rat primary astrocytes was significantly decreased by treatment with leptin. Leptin inhibited glutamate-induced phosphorylation of ERK1/2 in astrocytes. The leptin S120A/T121A mutant did not inhibit glutamate-induced ERK1/2 phosphorylation and ERK1/2mediated apoptosis. Conclusions: Collectively, our results provide initial evidence that leptin exerts an anti-apoptotic effect against glutamate toxicity through activation of intracellular signaling pathways which reverse glutamate-induced ERK1/2 phosphorylation in primary astrocytes. Therefore, our findings suggest that leptin might be considered a candidate for potential therapeutic applications in glutamate-induced brain excitotoxicity.
\end{abstract}

\section{Introduction}

(C) 2017 The Author(s)

Published by S. Karger AG, Basel

Astrocytes are the most abundant cells in the brain and play a multifunctional role in the central nervous system (CNS) [1], including metabolic and trophic support of neurons,

Youn-Hee Choi

KARGER
Department of Physiology, School of Medicine, Ewha Womans University, 911-1 Mok-dong Yangcheon-gu, Seoul, (Korea)

Tel. +82-2-2650-5838, Fax +82-2-2650-5717, E-Mail yc@ewha.ac.kr 


\section{Cellular Physiology Cell Physiol Biochem 2017;44:2117-2128 \begin{tabular}{l|l} 
DOI: 10.1159/000485950 & $\begin{array}{l}\text { O 2017 The Author(s). Published by S. Karger AG, Basel } \\
\text { www.karger.com/cpb }\end{array}$
\end{tabular} \\ Park et al.: Leptin Inhibits Glutamate-Induced Astrocyte Death}

maintenance and repair of the brain, and CNS synaptogenesis [2]. The metabolic function of astrocytes is to serve as the major storage site of glycogen and provide neurons with nutrients such as lactate and other trophic factors [3]. In addition, astrocytes are the cell type primarily responsible for glutamate uptake, although glutamate transporters are expressed by all CNS cell types [4-6]. Glutamate, the major excitatory neurotransmitter released at a majority of excitatory synapses in the CNS, depolarizes neurons by acting at specific receptors [7]. Glutamate uptake into astrocytes is mediated mainly by two Na+-dependent transporters: glutamate aspartate transporter (GLAST/EAAT1) and glutamate transporter-1 (GLT-1/EAAT2), a family of high-affinity Na+-dependent glutamate transporters [4, 8, 9]. Because astrocytes make important contributions to CNS metabolism and glutamate dynamics, dysfunction of astrocytes leads to serious consequences on neuronal survival and CNS function. Excessive stimulation by high extracellular levels of glutamate results in a form of neuronal cell death called glutamate excitotoxicity [10-12]. Glutamate uptake by astrocytes can prevent excitotoxic extracellular glutamate elevation. However, excessive glutamate uptake by astrocytes can eventually lead to reduced astrocyte viability and impaired astrocyte function during cerebral ischemia [8, 9]. For example, previous studies have demonstrated that pathologically excessive glutamate is not only a neurotoxin, but also impairs astrocyte function and leads to glutamate-induced astrocyte death through sustained ERK1/2 activation [13].

Among the molecules that exert important protective effects against excitotoxicity and other forms of neuronal damage is leptin, a $16 \mathrm{kDa}$ polypeptide hormone that is produced and secreted predominantly by adipocytes $[14,15]$. Leptin plays a key role in regulating body weight homeostasis by inhibiting feeding behavior and stimulating energy expenditure [16]. Leptin circulates in the blood stream and crosses the blood-brain barrier by a saturable transport action to produce neurotrophic, proinflammatory, neuromodulatory, and neuroprotective effects [17-19]. Recent studies have demonstrated that expression of leptin and its receptors are widespread in the brain and associated with several essential neuronal cell signaling pathways, including those that promote cell survival [20]. Experiments performed using in vitro and in vivo models showed that leptin leads to neuroprotection in various models of neurodegenerative disease, including Parkinson's and Alzheimer's disease $[21,22]$. In addition to neuroprotection, previous studies have demonstrated that leptin plays a protective effect against glutamate-induced cytotoxicity in astrocytes [21]. The neuroprotective mechanisms of leptin against glutamate-induced cytotoxicity include the activation of Janus kinase 2 (JAK2)-signaling transducer and activator of transcription 3 (STAT3), extracellular signal-regulated protein kinases (ERK) and Akt signaling pathways in neuronal cells and neuroblastoma cells [23-25]. Although previous studies have shown that leptin-induced neuroprotection is associated with a reduction of excitotoxicity-induced cell death in astrocytes, the precise cellular and molecular mechanisms involved in this leptininduced protection of astrocytes against excitotoxicity remain to be solved.

This study investigates signaling pathways mediating the neuroprotective effects of leptin in astrocyte and suggests the possibility of the therapeutic application of leptin in the treatment of glutamate-mediated brain excitotoxicity. We herein demonstrate that leptin, but not the leptin S120A/T121A mutant which acts as an antagonist of leptin signaling, significantly prevents glutamate-induced cytotoxicity in primary astrocytes. We further find that this protective effect is mediated, at least in part, by the suppression of ERK1/2 activation and phosphorylation.

\section{Materials and Methods}

\section{Primary cortical astrocyte culture}

Primary cultures of the cerebral cortices astrocytes of 1-day-old Sprague-Dawley neonatal rats (DBL, Chungbuk, Korea) were performed as previously described [26]. Briefly, cortices were mechanically dissociated in MEM containing 10\% FBS, L-glutamine, $100 \mathrm{U} / \mathrm{mL}$ penicillin, and $10 \mu \mathrm{g} / \mathrm{ml}$ streptomycin to yield a single-cell suspension and plated in $75-\mathrm{cm}^{2}$ culture flasks ( 0.5 hemisphere/flask) at $37^{\circ} \mathrm{C}$ in $95 \%$ air 


\section{Cellular Physiology Cell Physiol Biochem 2017;44:2117-2128 \begin{tabular}{l|l|l}
\hline and Biochemistry $10.1159 / 000485950$ & $\begin{array}{l}\text { C) } 2017 \text { The Author(s). Published by S. Karger AG, Basel } \\
\text { www.karger.com/cpb }\end{array}$ \\
\hline
\end{tabular} \\ Park et al.: Leptin Inhibits Glutamate-Induced Astrocyte Death}

and $5 \% \mathrm{CO}_{2}$ at $95 \%$ relative humidity. After 2 weeks, the other cell types (oligodendrocytes and microglia) growing on the top of the astrocyte were detached from flasks by shaking and the medium was replaced with a medium containing 5\% FBS. The attached cells were cultured for 1 more week. The cultured astrocytes were detached using trypsin/EDTA. Depending on the planned experiment, the primary astrocytes were reseeded on the following: 6 well tissue culture dishes (in a volume of $2 \mathrm{ml}$ per dish) and 96-well plates $(100 \mu \mathrm{l}$ per well). Astrocyte-enriched cultures were assessed by staining for glial fibrillary acidic protein (GFAP).

Reagents and antibodies

Recombinant rat leptin were purchased from PeproTech (Rocky Hill, NJ). Glutamate was purchased from Sigma-Aldrich, Co (St. Louis, MO, USA). Minimum essential medium (MEM) was purchased from WelGENE (WelGENE Inc. Daegu, Korea). Fetal bovine serum (FBS) was purchased from Gibco (Gibco, Grand Island, USA). Glutamate was purchased from Sigma. ERK 1/2, p-ERK 1/2, p38, p-p38, JNK, p-JNK, P-STAT3 (Tyr705), P-STAT3 (Ser727), AKT, P-AKT (Thr308), P-AKT (Ser473) to p-STAT3 (Tyr705), p-STAT3 (Ser727), AKT, p-AKT (Thr308), p-AKT (Ser473) antibodies were from Cell Signaling Technologies (Danvers, MA, USA). Tubulin antibody was obtained from Sigma-Aldrich, Co. Horseradish peroxidase (HRP)-conjugated secondary, P-JAK2 antibodies for immunoblotting were obtained from Santa Cruz Biotechnology (Santa Cruz, CA, USA). P-ObR (Tyr1141) antibodies were from signalway antibody Inc (College Park, Maryland, USA). The ERK inhibitor PD98059, JNK inhibitor SP600125, and p38 inhibitor SB203580 were purchased from Sigma-Aldrich, Co. Coomassie brilliant blue (CBB) staining solution was purchased from ATTO (ATTO, Tokyo, Japan).

\section{Protein expression and purification}

Recombinant leptin and leptin S120A/T121A mutant constructs were produced by consecutively subcloning the protein coding regions of leptin into the pRSETA vector (Invitrogen). Using these constructs, leptin and the leptin S120A/T121A mutant were overexpressed in Escherichia coli (BL21) as inclusion bodies, and the inclusion body proteins were purified as previously described $[27,28]$. Then, the inclusion body proteins of wild type leptin and S120A/T121A mutant leptin were refolded as previously described $[29,30]$. After refolding, wild type leptin and S120A/T121A mutant leptin proteins were purified by gelfiltration chromatography. All proteins were concentrated and PBS buffer was exchanged with a Centricon apparatus (Satorius Stedim Biotech, Germany). Endotoxins were removed via polymyxin B-agarose (SigmaAldrich). The Limulus Amebocyte Lysate (LAL) test was used to monitor endotoxin activity before and after endotoxin removal. Proteins were quantified using the bicinchoninic acid (BCA) assay, then filtered and stored at $4{ }^{\circ} \mathrm{C}$ until use.

\section{Cell viability assays}

Primary culture astrocyte cells were seeded on 96-well plates and incubated at 37 a for $1 \mathrm{~h}$ in the presence or absence of various concentrations of leptin or glutamate. Then, $10 \mu \mathrm{L}$ of $5 \mathrm{mg} / \mathrm{mL}$ of 3-(4, 5-dimethylthiazol-2-yl)-2, 5-diphenyltetrazolium bromide (MTT) was added to each well and cells were cultured for 4 hours at $37^{\circ} \mathrm{C}$. The supernatant was aspirated and $0.5 \mathrm{M}$ DMSO (Sigma-Aldrich co.) was added. The absorbance at $450 \mathrm{~nm}$ was detected with a microplate reader (VERSA max microplate reader, Molecular Devices, Sunnyvale, CA, USA).

\section{Apoptosis assay}

The proportion of apoptotic cells was measured by flow cytometry using a fluorescein isothiocyanate (FITC)-Annexin V apoptosis detection kit (BD Biosciences, San Jose, California). Primary cultured astrocytes were seeded in 6-well tissue culture plates and incubated overnight. After leptin pretreatment, cells were treated glutamate and then detached by trypsin. For annexin V/PI analysis, cells were harvested and stained with $5 \mu$ annexin V and PI according to the manufacturer's instruction. Apoptosis levels were detected by on LSR-II flow cytometer (BD Biosciences).

\section{Western blot analysis}

Primary astrocytes were pretreated with leptin for $1 \mathrm{~h}$ and then treated with $10 \mathrm{mM}$ glutamate for 1 h. Cell lysates were prepared with lysis buffer $\left(10 \mathrm{mM} \mathrm{Na}_{2} \mathrm{HPO}_{4}\right.$ (pH7.2), $150 \mathrm{mM} \mathrm{NaCl}, 1 \mathrm{mM}$ EDTA, $1 \%$ NP- 


\section{Cellular Physiology Cell Physiol Biochem 2017;44:2117-2128 \begin{tabular}{l|l} 
DOI: 10.1159/000485950 & $\begin{array}{l}\text { O 2017 The Author(s). Published by S. Karger AG, Basel } \\
\text { www.karger.com/cpb }\end{array}$
\end{tabular} \\ Park et al.: Leptin Inhibits Glutamate-Induced Astrocyte Death}

40, 0.1\% SDS, 0.5\% sodium deoxyclolate) supplemented with Xpert protease inhibitor cocktail (GenDEPOT, Inc., Baker, TX, USA). Total proteins were resolved on 12\% SDS-polyacrylamide gels and transferred onto polyvinylidene fluoride membranes (PVDF) (Amersham Pharmacia Biotech, Uppsala, Sweden). Membranes were blocked in 5\% skim milk in Tris-buffered saline containing 0.1\% Tween-20 (TBST) for $1 \mathrm{~h}$ at room temperature and then incubated with anti-ERK1/2, anti-phospho-ERK1/2 (Cell Signaling Technologies), anti-p38, anti-phospho-p38, anti-JNK, anti-phospho-JNK, and anti-Qd-tubulin antibodies overnight at $4^{\circ} \mathrm{C}$. After three washes with $0.1 \%$ TBST, blots were incubated with goat anti-rabbit or anti-mouse peroxidaseconjugated secondary antibody (Santa Cruz Biotechnology) for $2 \mathrm{~h}$ and washed with $0.1 \%$ TBST. Western blot bands were developed by the enhanced chemiluminescence (ECL) method (GE healthcare, Buckinghamshire, UK).

\section{Statistical analysis}

Statistical analyses were performed using the Student's $t$ test to compare between sample groups, and ANOVA was used to determine differences among multiple groups. Statistical significant differences were defined as $P<0.05$.

\section{Results}

Glutamate induces extracellular signal-regulated kinases (ERK) 1/2-dependent apoptosis in rat primary astrocytes

Previous studies have demonstrated that pathologically excessive glutamate results in glutamate-induced astrocyte death through sustained ERK1/2 activation [25]. To determine whether glutamate influences the viability of rat primary astrocytes, an MTT assay was performed to assess the dose-dependent toxicity of glutamate. As shown in Fig. 1A, the viability of primary astrocytes was not affected by 1-h incubation with glutamate at up to 5 $\mathrm{mM}$, but increasing concentrations of glutamate to doses of 10,50 , and $100 \mathrm{mM}$ significantly decreased cell viability of primary astrocytes. At $10 \mathrm{mM}$ of glutamate, cell viability reached $\sim 30-40 \%$ of untreated control cells, so we used this concentration for all subsequent experiments. To determine whether reduced viability of astrocytes induced by glutamate was associated with apoptosis, we performed Annexin V-FITC/PI flow cytometry analysis. After 1-h incubation with glutamate at $10 \mathrm{mM}$, approximately $46.5 \%$ of astrocytes were detected as undergoing either cell early or late apoptosis (Fig. 1B).

Saito and kinga demonstrated that ERK1/2 phosphorylation was induced by glutamate in cultured primary astrocytes [25]. To determine the early signaling events underlying glutamate-induced apoptosis of astrocytes, phosphorylation along the MAPK signaling pathway was analyzed using western blot analysis. At $1 \mathrm{~h}$ incubation with 1-10 mM of glutamate, phosphorylation of ERK1/2 and p38 was observed in a dose-dependent manner, but no changes were detected in JNK phosphorylation (Fig. 1C). Using specific inhibitors for p38, ERK1/2, or JNK, we next examined the major signaling pathways responsible for glutamate-induced apoptosis in primary astrocytes. The cultured astrocytes were pretreated with the p38, ERK1/2, or JNK specific inhibitors SB203580, PD98059, or SP600125 respectively, before $1 \mathrm{~h}$ glutamate incubation (Fig. 1D). Pretreatment with PD98059 significantly inhibited glutamate-induced apoptosis in primary astrocytes (43\% reduction relative to the glutamate-treated group, $\mathrm{P}<0.05$ ). However, no significant change was observed in response to the JNK inhibitor and p38 inhibitor under the same conditions. These results indicate that glutamate induces apoptosis in rat primary astrocytes mainly via activation of ERK1/2.

\section{Leptin suppresses glutamate-induced cytotoxicity in primary astrocytes}

We next evaluated the effect of exogenous leptin on the cell viability and phosphorylation of MAPK signaling in rat primary astrocytes using the MTT assay and western blot analysis. As shown in Fig. 2A, the viability of primary astrocytes was not affected by $24 \mathrm{~h}$ incubation with leptin at up to $100 \mathrm{ng} / \mathrm{ml}$. The level of phosphorylation of JNK and p38-MAPK was 


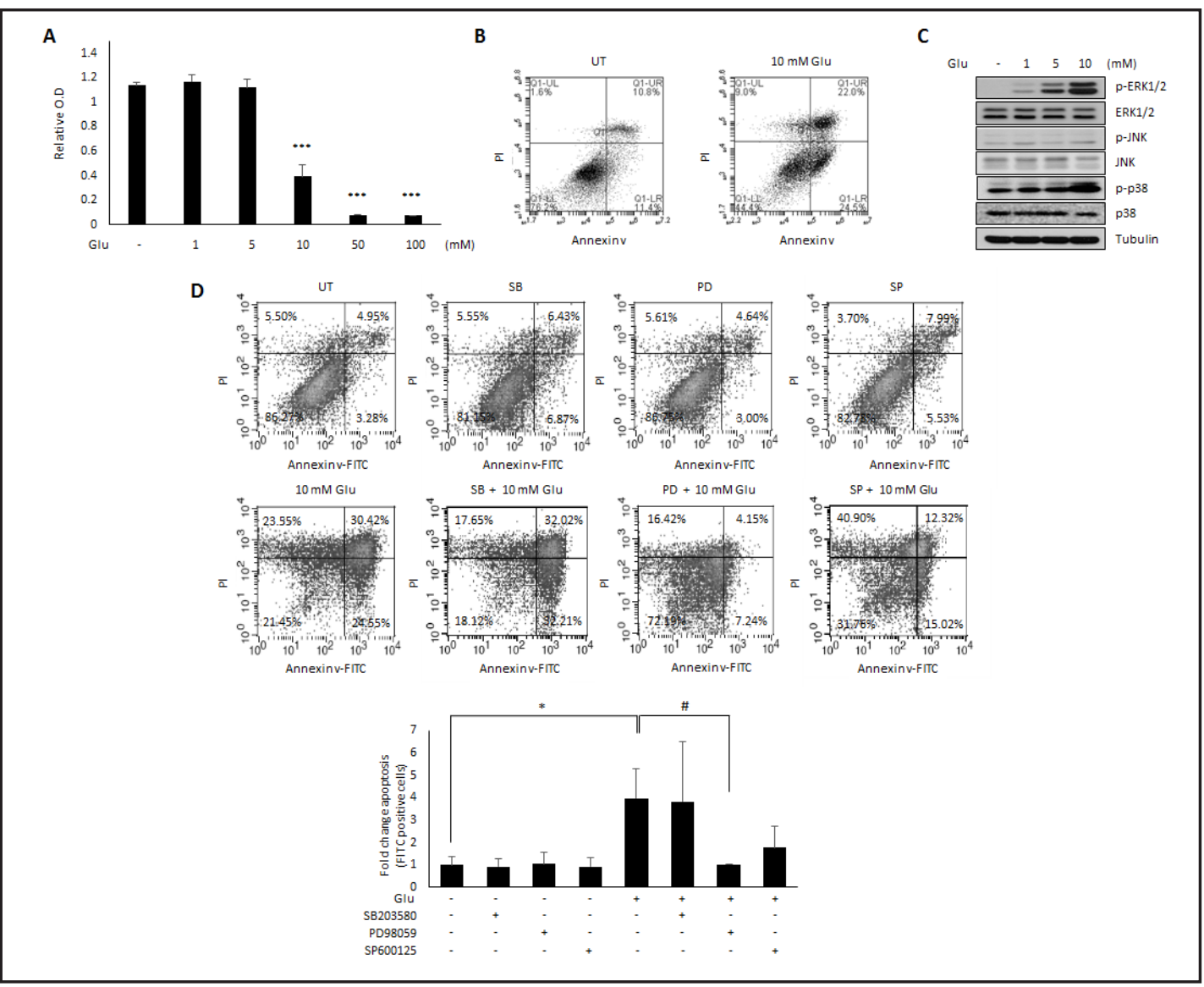

Fig. 1. Glutamate induces ERK $1 / 2$ phosphorylation in brain astrocytes. (A) Rat primary astrocytes were plated and treated with increasing concentrations of glutamate (1-100 mM) for $1 \mathrm{~h}$. MTT was further incubated for $4 \mathrm{~h}$ and absorbance was measured at $570 \mathrm{~nm}$ using a 96-plate reader to measure cell proliferation. (B) Cells were treated with $10 \mathrm{mM}$ glutamate for $1 \mathrm{~h}$, then stained with Annexin $\mathrm{V}$ and propidium iodide (PI). Apoptosis was quantified by flow cytometry. (C) Astrocytes were treated with $10 \mathrm{mM}$ glutamate for $1 \mathrm{~h}$ and then whole-cell lysates were extracted in RIPA buffer and subjected to immunoblotting analysis. Blots were probed with antibodies against p-ERK 1/2, p-JNK, p-p38, ERK 1/2, JNK, p38, and tubulin. (D) Cells were pretreated with p38 inhibitor SB203580 $(20 \mu \mathrm{M})$, extracellular signal-regulated kinases (ERK) 1/2 inhibitor PD98059 (20 $\mu \mathrm{M})$, and c-Jun N-terminal kinases (JNK) inhibitor SP600125 (20 $\mu \mathrm{M})$ for $30 \mathrm{~min}$. After those treatments, cells were incubated for $1 \mathrm{~h}$ followed by treatment with $10 \mathrm{mM}$ glutamate. The percentage of apoptotic primary astrocytes is shown in the bar diagram. Values are means \pm SD from three experiments. ${ }^{*} \mathrm{P}<0.05 ;{ }^{* * *} \mathrm{P}<0.001$ (VS control); ${ }^{*} \mathrm{P}<0.05$ (VS glutamate-treated cells).

also not changed in leptin-treated astrocytes compared to control while phosphorylation of ERK1/2 was slightly increased. To assess whether leptin treatment decreased glutamateinduced astrocyte apoptosis, we performed Annexin V-FITC/PI flow cytometry analysis. Similar results were obtained for the glutamate-treated group with regard to early and late apoptosis in primary astrocytes as in the previous experiments. However, after treatment with leptin at $1 \mu \mathrm{g} / \mathrm{ml}$ for $1 \mathrm{~h}$ together with glutamate, glutamate-induced apoptosis was significantly reduced (Fig. 2B).

\section{Leptin inhibits glutamate-induced phosphorylation of ERK1/2 in astrocytes}

To elucidate the neuroprotective mechanisms of leptin against glutamate toxicity in astrocytes, we pretreated primary astrocytes with $1 \mu \mathrm{g} / \mathrm{ml}$ leptin for $1 \mathrm{~h}$ and analyzed MAPK signaling pathways, such as ERK1/2, p38, and JNK by immunoblotting. After leptin 
A

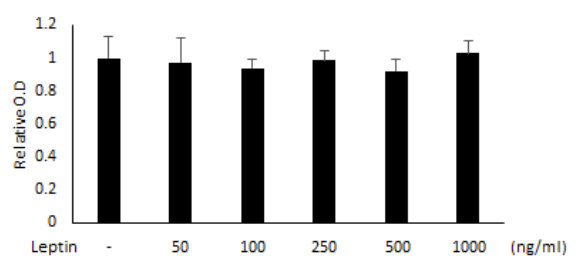

C
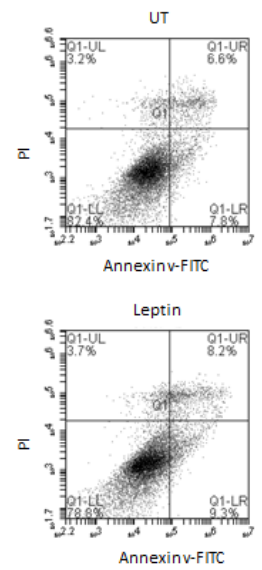
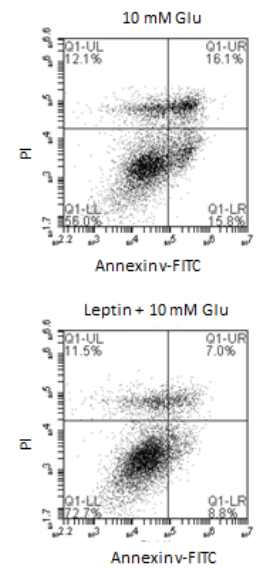

B
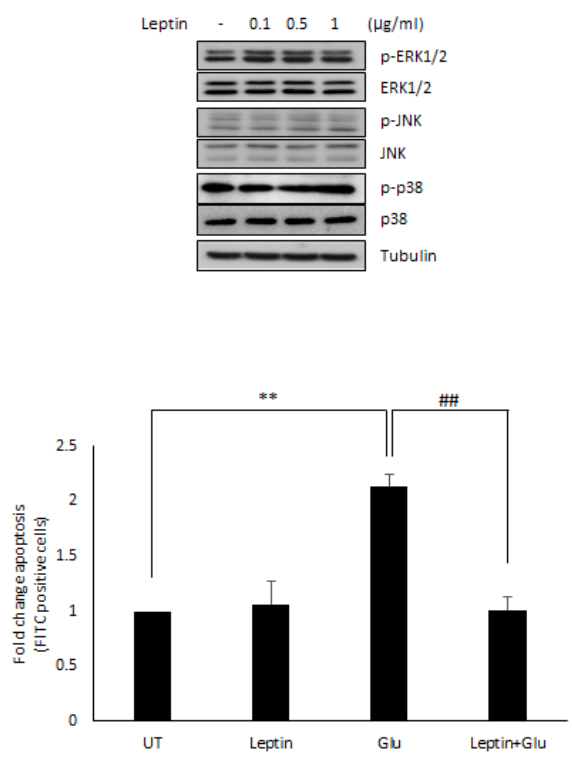

Fig. 2. Leptin inhibits glutamate-induced apoptosis in astrocytes. (A) Primary astrocytes were seeded and treated with 50-100 ng/ml leptin for $1 \mathrm{~h}$. The MTT assay was performed to monitor the proliferation rate of primary astrocytes. The optical density of each well was measured with a microplate spectrophotometer at $470 \mathrm{~nm}$. Results are expressed as fold change relative to cells and are representative of three different experiments each performed in triplicate. (B) Different amounts of leptin were applied to primary astrocytes. Cell lysates in cold-RIPA buffer were extracted and analyzed by immunoblotting. Anti-p-ERK 1/2, p-JNK, p-p38, ERK 1/2, JNK, p38, and anti-tubulin antibodies were used. (C) Primary astrocytes were pretreated with 1 $\mu \mathrm{g} / \mathrm{ml}$ leptin for $1 \mathrm{~h}$, followed by exposure to $10 \mathrm{mM}$ glutamate for $1 \mathrm{~h}$. Cells were harvested and stained with Annexin V-FITC/PI, as described in the methods and analyzed using flow cytometry. Apoptosis rate is expressed as a $\%$ of the total cell population. Data shown represent at least three experiments. ${ }^{* *} \mathrm{P}<0.01$ (VS control); ${ }^{\# \#} \mathrm{P}<0.01$ (VS glutamate-treated cells).

treatment, the level of phosphorylation of ERK1/2 was decreased in astrocytes compared with the glutamate-treated group, as determined by densitometry of immunoblots (Fig. 3, lanes 2 and 6-8). However, treating astrocytes with leptin had no effect on p-JNK and p-p38. To address the upstream intracellular signaling pathways activated by leptin, we performed immunoblotting against p-ObR (Tyr1141), p-JAK2/STAT3 and p-Akt signaling pathways. We found that the level of p-ObR (Tyr1141), p-JAK2 and p-STAT3 was increased by leptin treatment in astrocytes similar to previous study [24], while the level of p-AKT was not affected (Fig. 3A, lanes 3-5). Interestingly, when we treated cells with glutamate and leptin together, leptin-induced ObR phosphorylation at Tyr1141 was slightly dephosphorylated by co-treatment of glutamate and leptin. Moreover, glutamate-induced phosphorylation of ERK1/2, AKT, ObR (Tyr1141), JAK2, and STAT3 were decreased by leptin treatment in a dose-dependent manner (Fig. 3A, lanes 6-8). These results suggest that leptin modulates the extent of phosphorylation of leptin receptor $\mathrm{ObR}$ in the presence of glutamate and leads to suppression of glutamate-induced phosphorylation of signaling pathways especially ERK1/2 in primary astrocytes. 


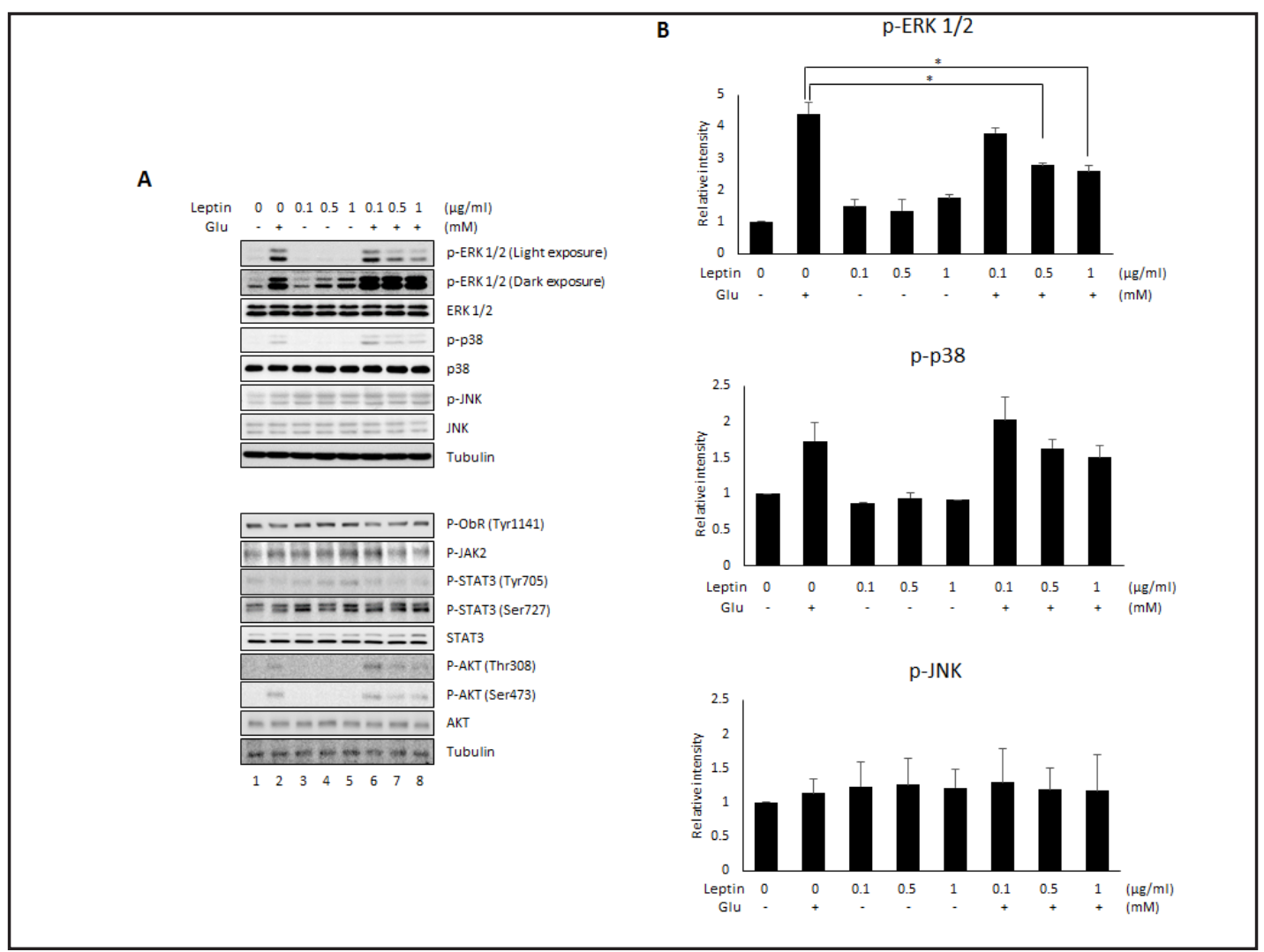

Fig. 3. Leptin abrogates glutamate-induces ERK $1 / 2$ phosphorylation in brain astrocytes. Astrocytes were pretreated with $0.1,0.5$, and $1 \mu \mathrm{g} / \mathrm{ml}$ leptin for $1 \mathrm{~h}$, then incubated for an additional $1 \mathrm{~h}$ followed by treatment with $10 \mathrm{mM}$ glutamate for $1 \mathrm{~h}$. After treatment, whole cell lysates from each group were extracted and subjected by immunoblotting analysis. Blots were probed with anti-p-ERK 1/2, p-p38, p-JNK, P-ObR (Tyr1141), P-JAK2, P-STAT3 (Tyr705), P-STAT3 (Ser727), P-AKT (Thr308), P-AKT (Ser473) to p-ObR(Tyr1141), p-JAK2, p-STAT3 (Tyr705), p-STAT3 (Ser727), p-AKT (Thr308), p-AKT (Ser473) and anti-tubulin antibodies. Densitometric quantification of p-ERK 1/2 levels, p-p38 levels and p-JNK levels normalized to the level of total tubulin. The p-ERK 1/2, p-p38 and p-JNK blots from three independent samples were quantified by densitometry. ${ }^{*} \mathrm{P}<0.05$.

Mutant S120A/T121A leptin antagonist is unable to inhibit glutamate-induced ERK1/2 phosphorylation in astrocytes

The S120A/T121A mutation yields a form of leptin that has a normal binding capacity to LR but an inability to activate the receptor completely [31]. Therefore, the S120A/T121A leptin mutant is known to behave as a direct antagonist blocking LR activation. The purity and homogeneity of the purified recombinant wild-type leptin and mutant S120A/T121A leptin proteins were analyzed by sodium dodecyl sulfate polyacrylamide gel electrophoresis (SDSPAGE) (Fig. 4A). We found that strong phosphorylation of Ob-Rb at Tyr1138/Tyr1141 was observed in primary astrocytes in response to wild-type leptin, but not leptin S120A/T121A mutant protein, indicating that S120A/T121A lacks the ability to activate and phosphorylate the leptin receptor (Fig. 4B). To confirm that leptin effects on glutamate-induced astrocyte death are mediated through LR, glutamate excitotoxicity assays were conducted in the presence of S120A/T121A leptin mutant and leptin wild type protein. Cells were exposed to wild type leptin or S120A/T121A mutant leptin for $1 \mathrm{~h}$ in the presence or absence of glutamate, and then flow cytometry analysis was performed. As expected, wild type leptin had a positive effect on cell viability in response to glutamate, but this effect disappeared if cells were treated with S120A/T121A mutant leptin (Fig. 4C). Next, to further confirm the S120A/T121A mutant leptin, phosphorylation of MAPK subfamilies in rat primary 


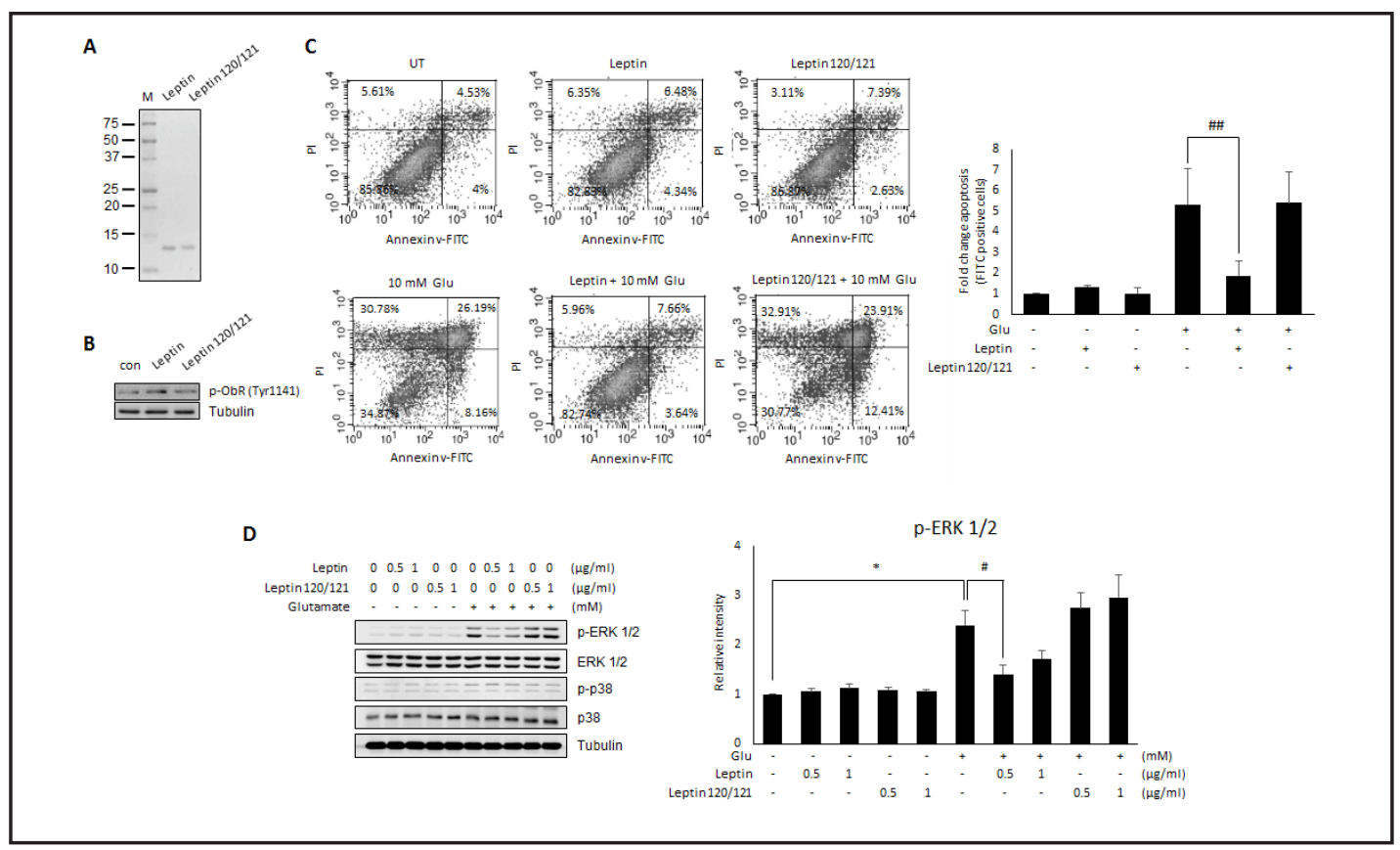

Fig. 4. Leptin antagonist S120A/T121A mutant protein does not abrogates glutamate-induced ERK1/2 phosphorylation in astrocytes. (A) The purified proteins were analyzed on a 15\% SDS-polyacrylamide gel, and the wild-type and S120A/T121A mutant leptin protein bands were stained with Coomassie Brilliant Blue R250. (B) Western analysis verified leptin receptor Tyr1141 phosphorylation expression in the presence of leptin or leptin S120A/T121A mutant. (C) Primary astrocytes were pretreated with $1 \mu \mathrm{g} / \mathrm{ml}$ leptin or leptin S120A/T121A mutant protein for $1 \mathrm{~h}$, followed by glutamate $(10 \mathrm{mM})$ for another $1 \mathrm{~h}$. The cells were stained with FITC-labeled annexin V and PI, and then analyzed by flow cytometry. Shown are quantitative results of the flow cytometric analysis $(n=3)$, expressed as the percentages of the apoptotic cells in the population. (D) Western blot analysis using phospho-ERK 1/2, p-p38, ERK 1/2, p38, tubulin antibodies in extracts from primary astrocytes, untreated $(-)$ or glutamate-treated $(10 \mathrm{mM})$ in the presence of leptin or leptin S120A/T121A mutant. Densitometric quantification of p-ERK 1/2 levels, normalized to the level of total ERK. ${ }^{*} \mathrm{P}<0.05$ (VS control); ${ }^{\#} \mathrm{P}<0.05 ;{ }^{\#} \mathrm{P}<0.01$ (VS glutamate-treated cells).

astrocytes was assessed by immunoblotting similar to before. When leptin was administered with glutamate, we observed a significant decrease of p-ERK1/2, but not p-p38, compared with glutamate only-treated cells. However, cotreatment with S120A/T121A mutant leptin did not have an effect on ERK1/2 phosphorylation relative to the glutamate-treated group (Fig. 4D). These results indicate that glutamate can induce astrocyte death and that leptin effectively inhibits glutamate-induced apoptosis in cultured primary astrocytes via LR.

Leptin has a protective effect against glutamate-induced apoptosis but is not effective against apoptosis induced by $\mathrm{H}_{2} \mathrm{O}_{2}$ or $\mathrm{CoCl}_{2}$

Previous studies demonstrated that hydrogen peroxide $\left(\mathrm{H}_{2} \mathrm{O}_{2}\right)$ and hypoxia $\left(\mathrm{CoCl}_{2}\right)$ induce apoptosis in cultured primary astrocytes [32-34]. Whether leptin has anti-apoptotic and necrotic effect on oxidative stress-induced apoptosis was evaluated using Annexin V-FITC/PI double staining monitored by flow cytometry. Primary astrocytes were pre-treated with $1 \mu \mathrm{g} / \mathrm{ml}$ leptin for $1 \mathrm{~h}$, followed by treatment with $10 \mathrm{mM}$ glutamate for $1 \mathrm{~h}$. Increases in the number of dying cells in response to $10 \mathrm{mM}$ glutamate was abolished when cells were pretreated with $1 \mu \mathrm{g} / \mathrm{ml}$ leptin. However, when cells were treated with $\mathrm{H}_{2} \mathrm{O}_{2}$ or $\mathrm{CoCl}_{2}$, the percentage of apoptotic and necrotic primary astrocytes was not changed by treatment with leptin (Fig. 5). These results indicate that leptin exerts a protective effect on glutamateinduced apoptosis, but not on $\mathrm{H}_{2} \mathrm{O}_{2}$ - or $\mathrm{CoCl}_{2}$-induced apoptosis in primary astrocytes. 


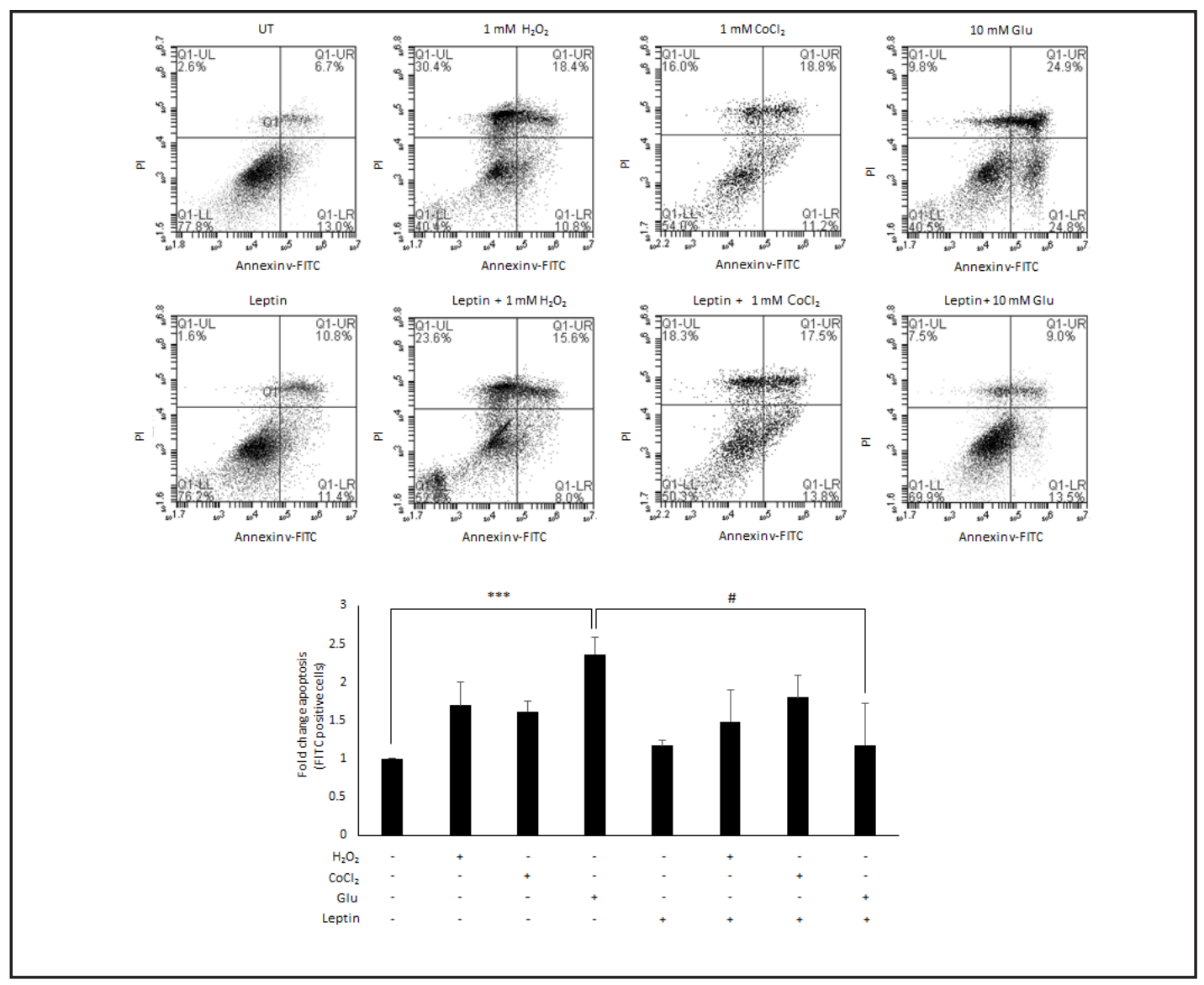

Fig. 5. Leptin does not have a protective effect against $\mathrm{H}_{2} \mathrm{O}_{2}$ - or $\mathrm{CoCl}_{2}$-induced apoptosis in rat primary astrocytes. FACS analysis of Annexin $\mathrm{V}$ positivity and propidium iodide after $1 \mathrm{~h}$ exposure of primary astrocytes to $1 \mathrm{mM} \mathrm{H}_{2} \mathrm{O}_{2}, 1 \mathrm{mM} \mathrm{CoCl}_{2}$ and $10 \mathrm{mM}$ glutamate in the presence of leptin. A representative analysis of 3 independent experiments is shown. ${ }^{* *} \mathrm{P}<0.001$ (VS control); ${ }^{*} \mathrm{P}<0.05$ (VS glutamate-treated cells).

\section{Discussion}

In this study, we demonstrate the novel finding that leptin suppresses glutamateinduced cytotoxicity in primary astrocytes by modulating ERK1/2 phosphorylation. Glutamate induced the phosphorylation of ERK1/2 and subsequent p-ERK1/2-dependent cell death, while leptin treatment prevented glutamate cytotoxicity. The leptin antagonizing S120A/T121A mutant did not inhibit glutamate-induced ERK1/2 phosphorylation and ERK1/2-mediated cytotoxicity. These results indicate that leptin exerts cytoprotective effect against glutamate via leptin receptor through suppression of glutamate-induced ERK1/2 phosphorylation in primary astrocytes.

Leptin modulates various biological functions by binding to its receptors, which are expressed both centrally and peripherally. Leptin signaling acts predominantly through the $\mathrm{LEP}-\mathrm{Rb}(\mathrm{OB}-\mathrm{Rb})$ long isoform of the leptin receptor. The LR initiates downstream signaling when coupled with JAK, leading to activation of STAT- pathway, MAPK pathway (especially ERK1/2 signaling), and the phosphatidylinositol-3-kinase $\left(\mathrm{PI}_{3} \mathrm{~K}\right) /$ Akt pathway $[35,36]$. Recent research suggests that the neuroprotection exerted by leptin in the CNS is associated with modulation of the MAPK/CREB pathway [37]. The PI3K/Akt pathway was also found 


\section{Cellular Physiology Cell Physiol Biochem 2017;44:2117-2128 \begin{tabular}{l|l|l} 
DOI: 10.1159/000485950 & $\begin{array}{l}\text { O 2017 The Author(s). Published by S. Karger AG, Basel } \\
\text { www.karger.com/cpb }\end{array}$
\end{tabular}

to be the critical pathway for the mediation of leptin-induced neuroprotection [38]. This study is the first to evaluate the LR-mediated protective effect of leptin utilizing leptin S120A/T121A mutant which is known to behave as an antagonist by blocking activation of LR-mediated intracellular signaling pathways. We showed that the S120A/T121A leptin mutant failed to prevent glutamate-induced ERK1/2 phosphorylation and cytotoxicity in astrocytes, indicating the importance of the presence of leptin receptor, leptin-LR binding, and subsequent activation of intracellular signaling cascades for optimal anti-apoptotic activity of leptin (Fig. 4).

Astrocytes, which represent the most abundant glial cell in the brain, actively participate in various brain functions such as homeostasis, buffering function, neuroprotective function and neuronal differentiation [39-42]. Recent studies demonstrated that LRs are expressed in the astrocytes and leptin and LRs play a role in various neuronal processes, including metabolism, neuroinflammation, morphology, and modulation of synaptic protein levels [43-46]. A novel finding of this study was that leptin suppressed glutamate-induced cytotoxicity, but not $\mathrm{H}_{2} \mathrm{O}_{2}$ - or $\mathrm{CoCl}_{2}$-induced cytotoxicity in primary astrocytes. Previously, it has been reported that leptin protects neuronal cells against ER stress through the PI3KmTOR pathway and exerts neuroprotective activities and neurotrophic effects on neuronal damage after acute brain injuries $[47,48]$. Leptin has proven to be an anticonvulsant in focal seizures model through the leptin receptor-mediated JAK2/PI3K signaling [49]. Shanley et al. demonstrated that leptin potently suppressed evoked epileptiform-like activity via PI3K activation of BK channels in rat hippocampal cells $[50,51]$. When we tested the protective effect of leptin against exogenous treatment of glutamate, $\mathrm{H}_{2} \mathrm{O}_{2}$ or $\mathrm{CoCl}_{2}$, we found that leptin had a protective effect specifically against glutamate-induced apoptosis, but is not effective against $\mathrm{H}_{2} \mathrm{O}_{2}$ - or $\mathrm{CoCl}_{2}$-induced apoptosis using primary astrocytes (Fig. 5). Together with previous reports demonstrating protective effect of leptin in neuronal cells, against seizure-induced neuronal injury our results for the protective effect of leptin in astrocytes collectively suggest that leptin may specifically contribute to the inhibition of glutamateinduced cytotoxicity both in neurons and glia.

Adding to previous findings on the neuroprotective effect of leptin, our results demonstrate for the first time that leptin, but not mutant leptin, effectively suppresses glutamate-induced cytotoxicity in primary astrocytes, as well. This suggests that leptin could be considered a potential candidate for the treatment of forms of brain damage associated with increased glutamate excitotoxicity, including hypoxia, ischemic brain injury, and epilepsy.

\section{Acknowledgements}

This work was supported by the National Research Foundation of Korea (NRF) grant funded by the Korea government (MSIT) 2010-0027945 and by NRF-2016R1A2B4016376 to YHC and NRF-2014R1A1A1006593 to HJP.

\section{References}

1 He F, Sun YE: Glial cells more than support cells? Int J Biochem Cell Biol 2007;39:661-665.

2 Brown AM, Ransom BR: Astrocyte glycogen and brain energy metabolism. Glia 2007;55:1263-1271.

-3 Nedergaard M, Ransom B, Goldman SA: New roles for astrocytes: redefining the functional architecture of the brain. Trends Neurosci 2003;26:523-530.

4 Anderson CM, Swanson RA: Astrocyte glutamate transport: review of properties, regulation, and physiological functions. Glia 2000;32:1-14.

5 Fairman WA, Amara SG: Functional diversity of excitatory amino acid transporters: ion channel and transport modes. Am J Physiol 1999;277:F481-486. 


\section{Cellular Physiology Cell Physiol Biochem 2017;44:2117-2128 \begin{tabular}{l|l|l} 
and BOI: 10.1159/000485950 & $\begin{array}{l}\text { C) } 2017 \text { The Author(s). Published by S. Karger AG, Basel } \\
\text { www.karger.com/cpb }\end{array}$
\end{tabular} \\ Park et al.: Leptin Inhibits Glutamate-Induced Astrocyte Death}

6 Kanai Y, Hediger MA: The glutamate and neutral amino acid transporter family: physiological and pharmacological implications. Eur J Pharmacol 2003;479:237-247.

7 Lovinger DM, Weight FF: Glutamate induces a depolarization of adult rat dorsal root ganglion neurons that is mediated predominantly by NMDA receptors. Neurosci Lett 1988;94:314-320.

8 Beart PM, O'Shea RD: Transporters for L-glutamate: an update on their molecular pharmacology and pathological involvement. Br J Pharmacol 2007;150:5-17.

-9 Rothstein JD, Dykes-Hoberg M, Pardo CA, Bristol LA, Jin L, Kuncl RW, Kanai Y, Hediger MA, Wang Y, Schielke JP, Welty DF: Knockout of glutamate transporters reveals a major role for astroglial transport in excitotoxicity and clearance of glutamate. Neuron 1996;16:675-686.

10 Verma A: Opportunities for neuroprotection in traumatic brain injury. J Head Trauma Rehabil 2000;15:1149-1161.

11 Froissard P, Duval D: Cytotoxic effects of glutamic acid on PC12 cells. Neurochem Int 1994;24:485-493.

12 Behl C, Widmann M, Trapp T, Holsboer F: 17-beta estradiol protects neurons from oxidative stress-induced cell death in vitro. Biochem Biophys Res Commun 1995;216:473-482.

13 Szydlowska K, Gozdz A, Dabrowski M, Zawadzka M, Kaminska B: Prolonged activation of ERK triggers glutamate-induced apoptosis of astrocytes: neuroprotective effect of FK506. J Neurochem 2010;113:904918.

14 Robaczyk M, Smiarowska M, Krzyzanowska-Swiniarska B: [The ob gene product (leptin)--a new hormone of adipose tissue]. Przegl Lek 1997;54:348-352.

15 Havel PJ: Role of adipose tissue in body-weight regulation: mechanisms regulating leptin production and energy balance. Proc Nutr Soc 2000;59:359-371.

-16 Halaas JL, Gajiwala KS, Maffei M, Cohen SL, Chait BT, Rabinowitz D, Lallone RL, Burley SK, Friedman JM: Weight-reducing effects of the plasma protein encoded by the obese gene. Science 1995;269:543-546.

17 Zhang Y, Proenca R, Maffei M, Barone M, Leopold L, Friedman JM: Positional cloning of the mouse obese gene and its human homologue. Nature 1994;372:425-432.

18 Pardridge WM: Receptor-mediated peptide transport through the blood-brain barrier. Endocr Rev 1986;7:314-330.

19 Maresh GA, Maness LM, Zadina JE, Kastin AJ: In vitro demonstration of a saturable transport system for leptin across the blood-brain barrier. Life Sci 2001;69:67-73.

20 Wu X, Hsuchou H, Kastin AJ, Mishra PK, Pan W: Upregulation of astrocytic leptin receptor in mice with experimental autoimmune encephalomyelitis. J Mol Neurosci 2013;49:446-456.

21 Marwarha G, Ghribi O: Leptin signaling and Alzheimer's disease. Am J Neurodegener Dis 2012;1:245-265.

22 Ho PW, Liu HF, Ho JW, Zhang WY, Chu AC, Kwok KH, Ge X, Chan KH, Ramsden DB, Ho SL: Mitochondrial uncoupling protein-2 (UCP2) mediates leptin protection against MPP+ toxicity in neuronal cells. Neurotox Res 2010;17:332-343.

-23 Russo VC, Metaxas S, Kobayashi K, Harris M, Werther GA: Antiapoptotic effects of leptin in human neuroblastoma cells. Endocrinology 2004;145:4103-4112.

-24 Guo Z, Jiang H, Xu X, Duan W, Mattson MP: Leptin-mediated cell survival signaling in hippocampal neurons mediated by JAK STAT3 and mitochondrial stabilization. J Biol Chem 2008;283:1754-1763.

25 Jayaram B, Khan RS, Kastin AJ, Hsuchou H, Wu X, Pan W: Protective role of astrocytic leptin signaling against excitotoxicity. J Mol Neurosci 2013;49:523-530.

26 Jo A, Park H, Lee SH, Ahn SH, Kim HJ, Park EM, Choi YH: SHP-2 binds to caveolin-1 and regulates Src activity via competitive inhibition of CSK in response to H2O2 in astrocytes. PLoS One 2014;9:e91582.

27 Kim J, Chwae YJ, Kim MY, Choi IH, Park JH, Kim SJ: Molecular basis of HLA-C recognition by p58 natural killer cell inhibitory receptors. J Immunol 1997;159:3875-3882.

-28 Patra AK, Mukhopadhyay R, Mukhija R, Krishnan A, Garg LC, Panda AK: Optimization of inclusion body solubilization and renaturation of recombinant human growth hormone from Escherichia coli. Protein Expr Purif 2000;18:182-192.

29 Park SM, Jung HY, Chung KC, Rhim H, Park JH, Kim J: Stress-induced aggregation profiles of GST-alphasynuclein fusion proteins: role of the C-terminal acidic tail of alpha-synuclein in protein thermosolubility and stability. Biochemistry 2002;41:4137-4146.

-30 Park SM, Ahn KJ, Jung HY, Park JH, Kim J: Effects of novel peptides derived from the acidic tail of synuclein (ATS) on the aggregation and stability of fusion proteins. Protein Eng Des Sel 2004;17:251-260. 


\section{Cellular Physiology Cell Physiol Biochem 2017;44:2117-2128 \begin{tabular}{l|l|l}
\hline DOI: 10.1159/000485950 & $\begin{array}{l}\text { C } 2017 \text { The Author(s). Published by S. Karger AG, Basel } \\
\text { www.karger.com/cpb }\end{array}$
\end{tabular} \\ Park et al.: Leptin Inhibits Glutamate-Induced Astrocyte Death}

-31 Peelman F, Van Beneden K, Zabeau L, Iserentant H, Ulrichts P, Defeau D, Verhee A, Catteeuw D, Elewaut D, Tavernier J: Mapping of the leptin binding sites and design of a leptin antagonist. J Biol Chem 2004;279:41038-41046.

-32 Park SJ, Lee JH, Kim HY, Choi YH, Park JS, Suh YH, Park SM, Joe EH, Jou I: Astrocytes, but not microglia, rapidly sense $\mathrm{H}(2) \mathrm{O}(2)$ via STAT6 phosphorylation, resulting in cyclooxygenase-2 expression and prostaglandin release. J Immunol 2012;188:5132-5141.

-33 Parpura V, Heneka MT, Montana V, Oliet SH, Schousboe A, Haydon PG, Stout RF, Jr., Spray DC, Reichenbach A, Pannicke T, Pekny M, Pekna M, Zorec R, Verkhratsky A: Glial cells in (patho)physiology. J Neurochem 2012;121:4-27.

34 Tiffany-Castiglioni E, Hong S, Qian Y: Copper handling by astrocytes: insights into neurodegenerative diseases. Int J Dev Neurosci 2011;29:811-818.

-35 Park HK, Ahima RS: Leptin signaling. F1000Prime Rep 2014;6:73.

-36 Ahima RS, Osei SY: Leptin signaling. Physiol Behav 2004;81:223-241.

-37 Cioffi JA, Shafer AW, Zupancic TJ, Smith-Gbur J, Mikhail A, Platika D, Snodgrass HR: Novel B219/OB receptor isoforms: possible role of leptin in hematopoiesis and reproduction. Nat Med 1996;2:585-589.

38 Zhang J, Deng Z, Liao J, Song C, Liang C, Xue H, Wang L, Zhang K, Yan G: Leptin attenuates cerebral ischemia injury through the promotion of energy metabolism via the PI3K/Akt pathway. J Cereb Blood Flow Metab 2013;33:567-574.

-39 Gadea A, Lopez-Colome AM: Glial transporters for glutamate, glycine, and GABA III. Glycine transporters. J Neurosci Res 2001;64:218-222.

-40 Deitmer JW, Rose CR: pH regulation and proton signalling by glial cells. Prog Neurobiol 1996;48:73-103.

41 Wilson JX: Antioxidant defense of the brain: a role for astrocytes. Can J Physiol Pharmacol 1997;75:11491163.

42 Signore AP, Zhang F, Weng Z, Gao Y, Chen J: Leptin neuroprotection in the CNS: mechanisms and therapeutic potentials. J Neurochem 2008;106:1977-1990.

43 Garcia-Caceres C, Fuente-Martin E, Burgos-Ramos E, Granado M, Frago LM, Barrios V, Horvath T, Argente J, Chowen JA: Differential acute and chronic effects of leptin on hypothalamic astrocyte morphology and synaptic protein levels. Endocrinology 2011;152:1809-1818.

44 Horvath TL, Sarman B, Garcia-Caceres C, Enriori PJ, Sotonyi P, Shanabrough M, Borok E, Argente J, Chowen JA, Perez-Tilve D, Pfluger PT, Bronneke HS, Levin BE, Diano S, Cowley MA, Tschop MH: Synaptic input organization of the melanocortin system predicts diet-induced hypothalamic reactive gliosis and obesity. Proc Natl Acad Sci U S A 2010;107:14875-14880.

45 Hsuchou H, He Y, Kastin AJ, Tu H, Markadakis EN, Rogers RC, Fossier PB, Pan W: Obesity induces functional astrocytic leptin receptors in hypothalamus. Brain 2009;132:889-902.

-46 Fuente-Martin E, Garcia-Caceres C, Granado M, de Ceballos ML, Sanchez-Garrido MA, Sarman B, Liu ZW, Dietrich MO, Tena-Sempere M, Argente-Arizon P, Diaz F, Argente J, Horvath TL, Chowen JA: Leptin regulates glutamate and glucose transporters in hypothalamic astrocytes. J Clin Invest 2012;122:3900-3913.

47 Thon M, Hosoi T, Yoshii M, Ozawa K: Leptin induced GRP78 expression through the PI3K-mTOR pathway in neuronal cells. Sci Rep 2014;4:7096.

48 Teryaeva NB: [Leptin as a neuroprotector and functional stability factor in the central neural system]. Ross Fiziol Zh Im I M Sechenova 2013;99:1138-1148.

49 Xu L, Rensing N, Yang XF, Zhang HX, Thio LL, Rothman SM, Weisenfeld AE, Wong M, Yamada KA: Leptin inhibits 4-aminopyridine- and pentylenetetrazole-induced seizures and AMPAR-mediated synaptic transmission in rodents. J Clin Invest 2008;118:272-280.

-50 Shanley LJ, O’Malley D, Irving AJ, Ashford ML, Harvey J: Leptin inhibits epileptiform-like activity in rat hippocampal neurones via PI 3-kinase-driven activation of BK channels. J Physiol 2002;545:933-944.

51 O'Malley D, Irving AJ, Harvey J: Leptin-induced dynamic alterations in the actin cytoskeleton mediate the activation and synaptic clustering of BK channels. FASEB J 2005;19:1917-1919. 